\title{
IA-2 antibodies - a sensitive marker of IDDM with clinical onset in childhood and adolescence
}

\author{
K.Savola ${ }^{1}$, E. Bonifacio ${ }^{2}$, E.Sabbah ${ }^{1}$, P.Kulmala ${ }^{1}$, P. Vähäsalo ${ }^{1}$, J. Karjalainen ${ }^{1}$, E. Tuomilehto-Wolf ${ }^{3}$, \\ J.Meriläinen ${ }^{4}$, H.K. Åkerblom 5 , M. Knip ${ }^{1,6}$ and the Childhood Diabetes in Finland Study Group \\ ${ }^{1}$ Department of Pediatrics, University of Oulu, Oulu, Finland \\ ${ }^{2}$ Scientific Institute of San Raffaele, Milan, Italy \\ ${ }^{3}$ National Public Health Institute, Helsinki, Finland \\ ${ }^{4}$ Department of Pathology, University of Oulu, Oulu, Finland \\ ${ }^{5}$ The Children's Hospital, University of Helsinki, Helsinki, Finland \\ ${ }^{6}$ Medical School, University of Tampere and Department of Pediatrics, Tampere University Hospital, Tampere, Finland
}

Summary To study the relationship of IA-2 antibodies (IA-2A) to other autoantibodies and genetic risk markers in insulin-dependent diabetes mellitus (IDDM), 758 children and adolescents younger than 15 years of age (mean age 8.4 years) with newly diagnosed diabetes were analysed for IA-2A, GAD antibodies (GADA) and insulin autoantibodies (IAA) with radiobinding assays, for islet cell antibodies (ICA) with immunofluorescence and for HLA DR alleles by serology. IA-2A were detected in $85.9 \%$ of cases with no association with gender or age. An overwhelming majority of the patients $(71.3 \%)$ tested positive for three or more antibodies, and $90.7 \%$ for at least two. Fifty-four subjects $(7.1 \%)$ had one antibody detectable, whereas only $2.1 \%$ of the patients tested negative for all four. A higher proportion of patients was positive for IA-2A and/or GADA than for ICA alone $(95.5$ vs $84.2 \%, p<0.001)$. The prevalence and level of IA-2A were increased in cases carrying HLA DR4/non-DR3 compared with other DR combinations. The results indicate that almost all patients with newly diagnosed childhood IDDM can be identified by screening with these four autoantibodies. The combination of IA-2A and/or GADA had a higher sensitivity for IDDM than ICA alone. The close association between IA-2A and HLA DR4, the strongest single allele predisposing to IDDM, suggests that IA-2A may be a more specific marker of beta-cell destruction than GADA, which have been shown to associate with the DR3 allele and thyroid autoimmunity. [Diabetologia (1998) 41: 424-429]

Keywords IA-2 antibodies, GAD antibodies, insulin autoantibodies, islet cell antibodies, HLA risk markers.
Insulin-dependent diabetes mellitus (IDDM) is the consequence of an autoimmune destruction of the pancreatic beta cells. Both humoral and cell-mediated immune responses to beta-cell antigens have

Received: 20 August 1997 and in final revised form: 13 November 1997

Corresponding author: Dr. M. Knip, Department of Pediatrics, University of Oulu, Kajaanintie 52 A, FIN-90220 Oulu, Finland Abbreviations: DiMe, the nationwide "Childhood Diabetes in Finland" study; GADA, antibodies against the $65 \mathrm{kDa}$ form of glutamic acid decarboxylase; IA-2A, antibodies against the intracellular portion of the IA-2 protein; IAA, insulin autoantibodies; ICA, islet cell antibodies; JDF-U, Juvenile Diabetes Foundation unit; RU, relative unit; TBST, buffer containing $50 \mathrm{mmol} / \mathrm{l}$ Tris, $150 \mathrm{mmol} / \mathrm{l} \mathrm{NaCl}(\mathrm{pH} \mathrm{7.4})$ and $0.1 \%$ Tween 20; WHO, World Health Organization. been observed [1]. Islet cell antibodies (ICA), now considered a heterogeneous series of antibodies against several beta-cell molecules, were first detected in 1974 [2], and insulin autoantibodies (IAA) were subsequently found in patients with newly diagnosed IDDM before exogenous insulin therapy [3]. Antibodies immunoprecipitating islet $64 \mathrm{kDa}$ proteins were also detected [4] and their target later identified as the $65 \mathrm{kDa}$ isoform of glutamic acid decarboxylase (GAD) [5]. More recently, antibodies against a protein tyrosine phosphatase-like transmembrane protein called the $40000 \mathrm{M}_{\mathrm{r}}$ protein [6], ICA512 [7] or IA-2 [8] were identified in patients with IDDM. Both ICA512 and IA-2 were characterized biochemically, and it turned out that they were identical in DNA sequence [9]. The $40 \mathrm{kDa}$ protein is a rat homologue of the intracellular portion of 
ICA512/IA-2 [10]. ICA512/IA-2 is expressed in neuroendocrine cells, including beta, alpha and delta cells in the pancreatic islets, pituitary cells and cells in the adrenal medulla $[9,11]$. Subcellularly, it is restricted to the membranes of neurosecretory granules $[9,11]$. It has been reported that $50-70 \%$ of patients with newly diagnosed diabetes have autoantibodies to ICA512/IA-2 [6, 9, 12]. We report here observations on antibodies to the intracellular portion of the IA-2 molecule (IA-2A) in relation to GAD antibodies (GADA), ICA, IAA and HLA DR alleles in a large population-based series of children with newly diagnosed IDDM.

\section{Subjects and methods}

Subjects. The population comprised 758 children under the age of 15 years (mean 8.4, range $0.78-14.97$ years) with newly diagnosed IDDM, including 418 boys, a male excess (55.1\%). The population included $93.5 \%$ of all IDDM patients in this age group diagnosed in Finland during the period from 1 September 1986 to 30 April 1989, and represents the index cases in the nationwide "Childhood Diabetes in Finland" (DiMe) study, which has been described in detail elsewhere [13]. The study protocol was approved by the ethical committees of all participating hospitals. Blood samples were taken at the time of diagnosis of diabetes and the sera were stored at $-20^{\circ} \mathrm{C}$ until assayed. Blood samples were in addition collected from 374 non-diabetic Finnish subjects aged 0-19 years to define the cut-off limits for positivity for IA-2A, GADA and IAA (defined as the 99th percentiles). The control population represents normal Finnish children and adolescents. The blood samples were taken after informed consent from the subjects and/ or the parents at child welfare clinics, schools or at prearranged visits to the outpatient clinic at the Department of Pediatrics, University of Oulu. The 105 control subjects used for assessing the 99th percentile of IAA were derived at random from the total group of 374 .

IA-2 antibody assay. IA-2A were analysed with a radiobinding assay modified from that described by Bonifacio et al. [14]. The recombinant plasmid pSP64poly(A) encoding the intracellular portion of the full length IA-2 protein, including amino acids 605-979 (provided by E. Bonifacio, Milan, Italy) was transformed in Escherichia coli JM109 cells and then purified by standard techniques [15]. The IA-2 protein was produced with in vitro transcription and translation of the purified plasmid by the TNT Coupled Reticulocyte Lysate System (Promega, Madison, Wis., USA) in the presence of ${ }^{35} \mathrm{~S}$-methionine (Amersham, Little Chalfont, Bucks, UK) according to the manufacturer's instructions. Unincorporated ${ }^{35} \mathrm{~S}$-methionine was removed by gel chromatography on a NAP-5 column (Pharmacia, Uppsala, Sweden). Serum samples of $2 \mu \mathrm{l}$ were incubated at $+4{ }^{\circ} \mathrm{C}$ overnight in 96 deep well plates with $10000 \mathrm{cpm}$ of labelled IA-2 protein diluted in $50 \mu \mathrm{l}$ of $50 \mathrm{mmol} / \mathrm{l}$ Tris and $150 \mathrm{mmol} / 1 \mathrm{NaCl}$ (pH 7.4) containing $0.1 \%$ Tween 20 (TBST). On the next day $5 \mu$ l Protein A Sepharose CL-4B (Pharmacia) in a total volume of $50 \mu \mathrm{l} \mathrm{TBST}$ was added to isolate the immune complexes. After incubation for at least $1 \mathrm{~h}$ on a shaker at $+4{ }^{\circ} \mathrm{C}$, the samples were transferred to a 96-well opaque filtration plate with a $0.45 \mu \mathrm{m}$ Durapore filter at the bottom of each well (Millipore, Bedford, Mass., USA). The samples were washed 10 times with approximately $150 \mu \mathrm{l}$ TBST using a vacuum device (Milli-

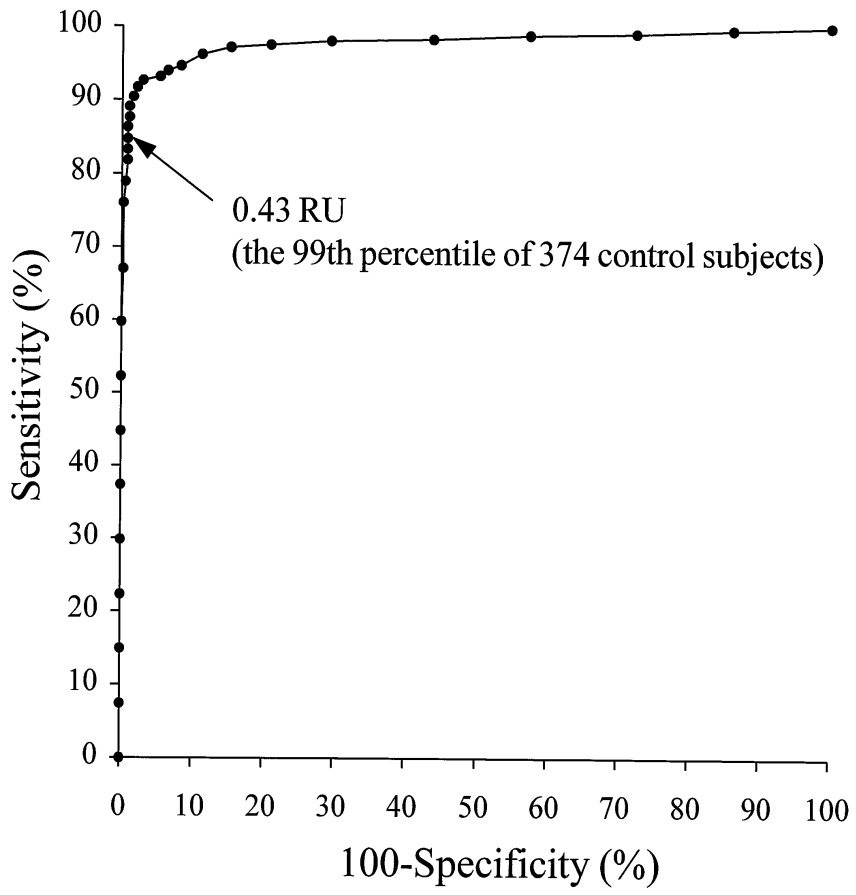

Fig. 1. Receiver operating characteristic (ROC) curve for IA$2 \mathrm{~A}$ measured by a radiobinding assay. The curve was generated by analysing 758 newly diagnosed IDDM patients and 374 control subjects

pore). After a short drying period, $10 \mu \mathrm{l}$ of scintillation fluid (OptiPhase Supermix; Wallac, Turku, Finland) was added and the activity of the samples was measured in a liquid scintillation counter (1450 Microbeta Trilux; Wallac). All the samples were tested in duplicate. In addition, each plate contained a dilution series of a pool of two local positive sera diluted in a pool of two local negative sera. A standard curve was constructed on each plate using the cpm results of the dilution series $(1: 2,1: 4$, $1: 8,1: 16,1: 32,1: 64,1: 128 ; 1: 512$ and the pool of the two negative sera), the dilution being assigned arbitrary values of 100, 50, 25, $12.5,6.25,3.125,1.56,0.78,0.39$ and 0.1 relative units (RU), respectively. The standard curve was a $\log _{10} / \log _{10}$ curve created separately for each plate by a software program (MultiCalc; Wallac), which was also used to handle the results and to combine the patient codes and relative units. The limit for positivity (0.43 RU) was set at the 99th percentile for 374 non-diabetic Finnish children and adolescents. All samples with IA-2A levels exceeding $100 \mathrm{RU}$ were diluted and reanalysed until the result could be read from the standard curve and the final IA-2A level was obtained by multiplying the relative units by the dilution factor. The receiver operating characteristic (ROC) curve based on the IA-2A levels in the 758 children with newly diagnosed diabetes and 374 unaffected Finnish children and adolescents is shown in Figure 1. The interassay coefficient of variation was $12 \%$ at an IA-2A level of 0.63 RU, $10 \%$ at a level of 21.3 RU and $8 \%$ at a level of 82.6 RU. The disease sensitivity of our assay was $62 \%$ and the specificity $97 \%$ based on 140 samples included in the 1995 Multiple Autoantibody Workshop.

GAD65 antibody assay. GADA were measured with a radioligand assay as previously described [16, 17]. The cut-off limit for antibody positivity was set at the 99th percentile for 372 non-diabetic children and adolescents, i.e. 6.6 RU. The interassay coefficient of variation was $18 \%$ at a GADA level of 14.6 RU and $12 \%$ at GADA levels exceeding 100 RU. The 
Table 1. Frequencies of autoantibody combinations in 758 children with newly diagnosed diabetes

\begin{tabular}{|c|c|c|c|c|c|c|}
\hline & \multirow{2}{*}{$\begin{array}{l}\text { All patients } \\
(n=758)\end{array}$} & \multicolumn{3}{|c|}{ Patients grouped by age } & \multicolumn{2}{|l|}{ Statistics } \\
\hline & & $\begin{array}{l}\text { I } \\
0-4.9 \text { years } \\
(n=166)\end{array}$ & $\begin{array}{l}\text { II } \\
5-9.9 \text { years } \\
(n=295)\end{array}$ & $\begin{array}{l}\text { III } \\
10-14.9 \text { years } \\
(n=297)\end{array}$ & $\chi^{2} d f=2$ & $\begin{array}{l}p \text { value } \\
n\end{array}$ \\
\hline IA-2A+ & 85.9 & 86.1 & 87.1 & 84.5 & 0.84 & 0.66 \\
\hline $\mathrm{IA}-2 \mathrm{~A}+, \mathrm{GADA}-$ & 22.6 & 25.9 & 26.4 & 16.8 & 9.18 & $<0.05$ \\
\hline $\mathrm{IA}-2 \mathrm{~A}+, \mathrm{ICA}-$ & 9.5 & 9.6 & 5.4 & 13.5 & 11.15 & $<0.01$ \\
\hline $\mathrm{IA}-2 \mathrm{~A}+$, IAA- & 42.0 & 22.9 & 45.4 & 49.2 & 32.56 & $<0.001$ \\
\hline No detectable antibodies & 2.1 & 0.6 & 1.7 & 3.4 & 4.34 & 0.11 \\
\hline One antibody positive & 7.1 & 6.6 & 5.1 & 9.4 & 4.30 & 0.12 \\
\hline Only IA-2A+ & 2.8 & 3.0 & 1.4 & 4.0 & 4.01 & 0.13 \\
\hline Two antibodies positive & 19.4 & 13.9 & 23.1 & 18.9 & 5.84 & 0.054 \\
\hline IA-2A+ and ICA+ & 9.2 & 7.2 & 13.2 & 6.4 & 9.24 & $<0.01$ \\
\hline $\mathrm{IA}-2 \mathrm{~A}+$ and IAA+ & 1.2 & 2.4 & 0.7 & 1.0 & 2.85 & 0.24 \\
\hline $\mathrm{IA}-2 \mathrm{~A}+$ and GADA+ & 3.7 & 0.6 & 2.4 & 6.7 & 13.62 & $<0.01$ \\
\hline Three antibodies positive & 39.8 & 34.9 & 41.4 & 41.1 & 2.14 & 0.34 \\
\hline IA-2A+, ICA+ and IAA+ & 9.4 & 13.3 & 11.2 & 5.4 & 9.64 & $<0.01$ \\
\hline $\mathrm{IA}-2 \mathrm{~A}+, \mathrm{ICA}+$ and GADA+ & 26.3 & 12.0 & 28.5 & 32.0 & 23.10 & $<0.001$ \\
\hline IA- $2 \mathrm{~A}+$, GADA + and IAA+ & 1.8 & 3.6 & 1.0 & 1.7 & 4.03 & 0.13 \\
\hline All four antibodies positive & 31.5 & 44.0 & 28.8 & 27.3 & 15.4 & $<0.001$ \\
\hline Multiple (at least three) antibodies positive & 71.4 & 78.9 & 70.2 & 68.4 & 6.16 & $<0.05$ \\
\hline
\end{tabular}

disease sensitivity of the assay was $65 \%$ and the specificity $97 \%$ based on the recent Multiple Autoantibody Workshop.

Islet cell antibody assay. ICA were measured by a standard immunofluorescence method, using sections of frozen human group 0 pancreas [2]. End-point dilution titres were examined for the positive samples, and the results were expressed in $\mathrm{Ju}-$ venile Diabetes Foundation (JDF) units relative to an international reference standard [18]. The detection limit was 2.5 JDF units. Our laboratory has participated in the international workshops on standardization of the ICA assay, in which its sensitivity was $100 \%$, specificity $98 \%$, validity $98 \%$, and consistency $98 \%$ in the most recent round [19].

Insulin autoantibody assay. Serum IAA levels were determined with a radiobinding assay modified from that described by Palmer et al. [3]. Endogenous insulin was removed with acid-charcoal before the assay, and free and bound insulin were separated after incubation with mono- ${ }^{125} \mathrm{I}\left(\mathrm{Tyr}^{\mathrm{A} 14}\right)$-human insulin (Novo Research Institute, Bagsvaerd, Denmark) for $20 \mathrm{~h}$ in the presence or absence of an excess of unlabelled insulin. IAA levels were expressed in $\mathrm{nU} / \mathrm{ml}$, where $1 \mathrm{nU} / \mathrm{ml}$ corresponds to a specific binding of $0.01 \%$ of the total counts. The interassay coefficient of variation was less than $8 \%$. A subject was considered to be positive for IAA, when specific binding exceeded $54 \mathrm{nU} / \mathrm{ml}$ (99th percentile for 105 non-diabetic subjects). The disease sensitivity of this assay was $26 \%$ and the specificity $97 \%$ based on 140 samples included in the Multiple Autoantibody Workshop.

HLA typing. HLA alleles were typed using conventional HLA serology as described previously [20]. All HLA DR specificities recognized by the Nomenclature Committee of the WHO in 1984 were included in the test panel [21]. HLA typing data were available for 730 of the patients.

Statistical analysis. The data were evaluated statistically using cross-tabulation and chi-square statistics, the MannWhitney U test, Kruskall-Wallis one-way ANOVA and Spearman's non-parametric correlation analysis $\left(r_{s}\right)$ (SPSS for Windows; SPSS Inc., Chicago, Ill., USA). The Bonferroni correction for multiple comparisons was performed, where appropriate. The results are expressed as proportions $[95 \%$ confidence intervals (CI)] or medians (range) unless otherwise indicated.

\section{Results}

Frequencies and levels of IA-2A. IA-2A were detected in 651 subjects $(85.9 \%$; CI $83.4-88.4 \%)$, the median level in whom was $64.5 \mathrm{RU}$, with a range of 0.45 to $4500 \mathrm{RU}$. The boys and girls had similar frequencies and levels of IA-2A. There were no significant differences in the IA-2A frequencies when the subjects were classified into three age groups (0-4.9, 5-9.9 and 10-14.9 years) (Table 1), but patients aged 5-9.9 years had higher IA-2A levels than the youngest children (63.8 RU vs. 17.4 RU, $p<0.01$ ). Among those with IA-2A, about one tenth tested negative for ICA, one fifth for GADA and more than $40 \%$ for IAA. These proportions varied, however, according to age (Table 1$)$.

Combinations and correlations between autoantibodies. The frequencies of various antibody combinations are given in Table 1 for both the whole study population and separately for the three age groups. An overwhelming majority of the patients $(71.4 \%$, CI $68.2-74.6 \%$ ) tested positive for at least three disease-associated autoantibodies, while $90.8 \%$ (CI 88.5-92.7\% ) were positive for two or more antibodies. Less than one tenth of the cases $(54 ; 7.1 \%$, CI $5.4-9.2 \%)$ had one antibody detectable, and only $2.1 \%$ (CI 1.2-3.4\%) tested negative for all four. The boys and girls had similar frequencies of multiple (at 


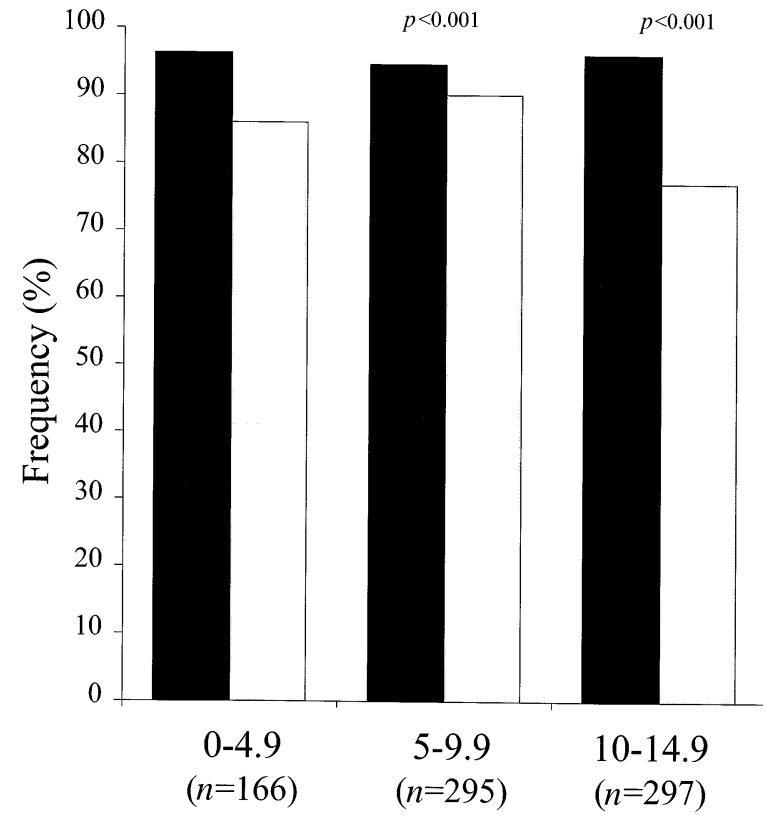

Fig. 2. Significantly more patients with newly diagnosed IDDM were identified by IA-2A and/or GADA ( $)$ than by ICA $(\square)$ alone. The difference was most conspicuous in the oldest age group

least three) autoantibodies (68.9\%, CI 64.5-73.3\% vs $74.4 \%, 69.8-79.1 \% ; p=0.11)$. A higher proportion of the patients tested positive for IA-2A and/or GADA than for ICA alone (95.5\%, CI 93.8-96.9\% vs $84.2 \%$, CI $81.6-86.8 \% ; p<0.001)$, the difference being most conspicuous in the oldest age group (Fig. 2). Both ICA and IA-2A and/or GADA were detected in 625 patients $(82.5 \%$, CI $79.7-85.2 \%)$, while 99 of the remaining cases $(13.1 \%$ of all patients, CI $10.7-15.5 \%$ ) were identified by IA-2A and/or GADA and not by ICA, as opposed to 13 $(1.7 \%$ of all cases, CI $0.9-2.9 \%)$ detected by ICA but not by IA-2A and/or GADA. There was a relatively close correlation $\left(r_{\mathrm{s}}=0.40, p<0.001\right)$ between IA-2A and ICA levels after the exclusion of double negative subjects, while a weak inverse correlation was seen between IA-2A and GADA levels $\left(r_{\mathrm{s}}=\right.$ $-0.09, p<0.05)$. Levels of IA-2A correlated weakly with those of IAA $\left(r_{\mathrm{s}}=0.08, p<0.05\right)$.

IA-2A and HLA risk markers. The prevalence of IA$2 \mathrm{~A}$ was higher in cases carrying the HLA DR4/nonDR3 phenotype and lower in those with the HLA DR3/non-DR4 combination than in the other HLA DR groups (Table 2), and the IA-2A levels followed the same pattern (Fig.3). The few patients with the DR2 allele ( $n=24,3.2 \%$ of all cases) had IA-2A as often as the other subjects ( 83.3 vs $85.7 \%, p=0.98$ ), and there was no significant difference in the IA-2A levels between those carrying the DR2 allele and the others (3.2 vs $44.2 \mathrm{RU} ; p=0.23$ ). The frequencies of ICA and IAA were decreased in the subjects with the HLA DR3/non-DR4 combination (Table 2). Multiple antibodies were less frequent in patients with HLA DR3/non-DR4 than in the patients with HLA DR3/DR4 or HLA DR4/non-DR3 (Table 2, $p<0.001$ for both comparisons).

\section{Discussion}

In the present study we found antibodies to IA-2 in a definite majority of children and adolescents with newly diagnosed IDDM (85.9\%), including 171 cases (22.6\% of all patients) with undetectable GADA. The prevalence of IA-2A observed in this Finnish cohort is high as compared with other reports. Both here and in a previous survey [22], IA-2A were found to be more prevalent in patients with HLA DR4, the frequency of which is particularly high in Finnish patients with IDDM [23]. Moreover, antibodies to the $37 / 40 \mathrm{kDa}$ protein have been reported previously to be associated with a young age at diagnosis [24, 25]. IA-2A were similarly found in a Belgian study to be more frequent in patients diagnosed before the age of 20 years than in those with clinical presentation at

Table 2. Frequencies (95\% CI) of IA-2A, GADA, ICA, IAA and multiple (at least three) autoantibodies in 730 children with newly diagnosed IDDM, by HLA DR status

\begin{tabular}{|c|c|c|c|c|c|c|}
\hline & \multirow{2}{*}{$\begin{array}{l}\mathrm{I} \\
\mathrm{DR} 3 / \mathrm{DR} 4 \\
(n=157)\end{array}$} & \multirow{2}{*}{$\begin{array}{l}\text { II } \\
\text { DR4/non-DR3 } \\
(n=421)\end{array}$} & \multirow{2}{*}{$\begin{array}{l}\text { III } \\
\text { DR3/non-DR4 } \\
(n=74)\end{array}$} & \multirow{2}{*}{$\begin{array}{l}\text { IV } \\
\text { Other DR alleles } \\
(n=78)\end{array}$} & \multicolumn{2}{|l|}{ Statistics } \\
\hline & & & & & $\chi^{2} d f=3$ & $p$ value \\
\hline IA-2A (\%) & $\begin{array}{l}80.9 \\
(73.9-86.7)\end{array}$ & $\begin{array}{l}92.4 \\
(89.4-94.7)\end{array}$ & $\begin{array}{l}58.1 \\
(46.1-69.5)\end{array}$ & $\begin{array}{l}84.6 \\
(74.7-91.8)\end{array}$ & $=64.1$ & $<0.001$ \\
\hline GADA (\%) & $\begin{array}{l}77.1 \\
(69.7-83.4)\end{array}$ & $\begin{array}{l}71.0 \\
(66.7-75.4)\end{array}$ & $\begin{array}{l}78.4 \\
(67.3-87.1)\end{array}$ & $\begin{array}{l}73.1 \\
(61.8-82.5)\end{array}$ & $=3.2$ & $=0.36$ \\
\hline $\operatorname{ICA}(\%)$ & $\begin{array}{l}82.2 \\
(75.3-87.8)\end{array}$ & $\begin{array}{l}86.2 \\
(82.9-89.5)\end{array}$ & $\begin{array}{l}73.0 \\
(61.4-82.6)\end{array}$ & $\begin{array}{l}87.2 \\
(77.7-93.7)\end{array}$ & $=9.3$ & $<0.05$ \\
\hline IAA (\%) & $\begin{array}{l}55.4 \\
(47.3-63.3)\end{array}$ & $\begin{array}{l}48.9 \\
(44.2-53.7)\end{array}$ & $\begin{array}{l}31.1 \\
(20.8-42.9)\end{array}$ & $\begin{array}{l}51.3 \\
(39.7-62.8)\end{array}$ & $=12.2$ & $<0.01$ \\
\hline Multiple antibodies (\%) & $\begin{array}{l}75.2 \\
(67.6-81.7)\end{array}$ & $\begin{array}{l}74.8 \\
(70.7-79.0)\end{array}$ & $\begin{array}{l}48.6 \\
(36.9-60.6)\end{array}$ & $\begin{array}{l}70.5 \\
(59.1-80.3)\end{array}$ & $=22.4$ & $<0.001$ \\
\hline
\end{tabular}




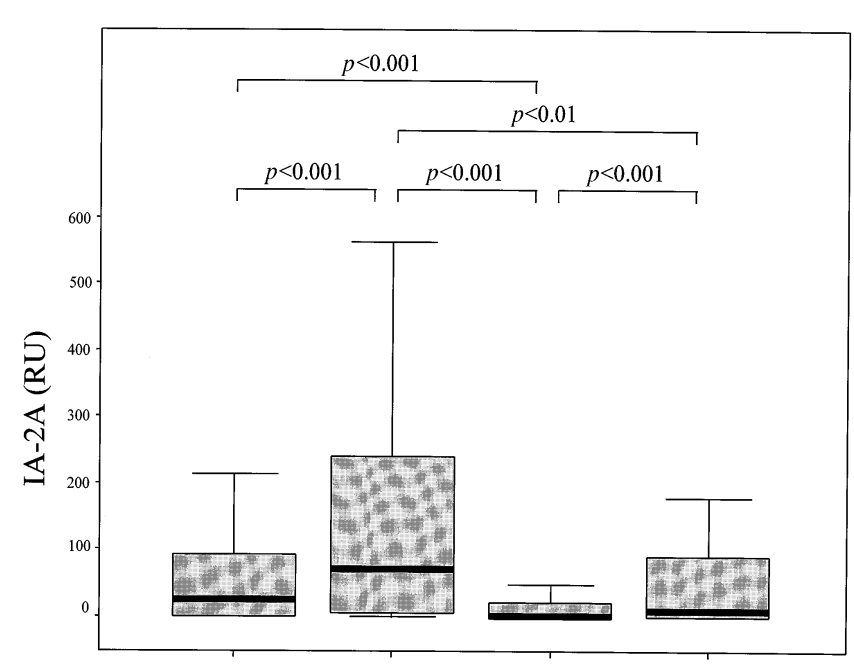

DR3/DR4 DR4/non-DR3 DR3/non-DR4 other DR alleles

Fig.3. IA-2A levels in 730 IDDM patients at the time of diagnosis by HLA DR status. Each box plot represents the median and the 25 th and 75 th percentiles. The error bars represent the lowest and highest values, excluding outliers

an older age [12]. Both the HLA characteristics and the age of the present cohort may therefore account for the high IA-2A prevalence.

The prevalence of IA-2A was similar in the girls and boys and in the children and adolescents. In this respect IA-2A differ from GADA, which are more frequent among girls and among patients over 10 years of age [17], and also from ICA and IAA, which are associated with young age at the diagnosis of IDDM [26, 27]. Moreover, IA-2A were closely associated with HLA DR4, the strongest single allele predisposing to IDDM, while high GADA levels have been reported to be associated with HLA DR3 and DQB1*02 $[17,28]$. These results indicate that IA-2A and GADA complement each other. Furthermore, GADA have been shown to be associated with thyroid microsomal and thyroglobulin antibodies both in patients with newly diagnosed IDDM and in their siblings [29]. This implies that GADA may be a sign of general autoimmunity in patients with IDDM, while IA- $2 \mathrm{~A}$ could be a more specific marker of beta-cell destruction. Our observation of a decreased frequency of ICA and IAA in patients carrying HLA DR3/ non-DR4 is consistent with most previous studies [28, 30, 31].

Measurement of a combination of autoantibody markers has been suggested as a useful tool for determining the risk of IDDM [32], and a number of screening strategies have been proposed [33]. The recent identification of IA-2 as an important IDDM associated autoantigen in addition to GAD has greatly facilitated the development of such strategies. In the present cohort $71.3 \%$ of the patients had at least three disease-associated autoantibodies, whereas only $2.1 \%$ (16 of 758) tested negative for all four, sug- gesting that almost all children with IDDM can be identified by screening for these four autoantibodies at diagnosis. The combination of IA-2A and/or GADA identified $95.5 \%$ of the cases, supporting previous suggestions that a combined GADA/IA-2A test is likely to be useful for screening purposes. Since $90.8 \%$ of all cases had at least two of the antibody markers tested, screening with IA-2A and GADA with subsequent testing of IAA and ICA in those found to be positive for IA-2A and/or GADA is likely to be an effective way of assessing the risk of IDDM. These antibodies are found prior to clinical disease onset and antibody measurements in preIDDM cases also show that a combination of GADA and IA-2A will be effective as a sensitive screen for future IDDM $[32,34]$. The risk estimates yielded by the various antibody combinations and the importance of IAA and ICA in screening strategies will need to be evaluated by additional prospective studies on individuals progressing to clinical IDDM.

In summary, we have found that IA-2A are present in the majority of children with newly diagnosed IDDM, that they differ from GADA in their relationship to age, sex and HLA DR alleles, and that in combination with GADA they serve to identify over $95 \%$ of newly diagnosed cases with diabetes.

Acknowledgements. This work was supported by the Foundation for Diabetes Research in Finland, the Juvenile Diabetes Foundation International (grants 188517 and 197032), the Novo Nordisk Foundation, the Medical Research Council of the Academy of Finland (grants 26109, 32757 and 44718) and the Alma and K. A. Snellman Foundation, Oulu, Finland. The "Childhood Diabetes in Finland" project has been supported by grants from the National Institutes of Health (grant DK37957), the Sigrid Jusélius Foundation, the Association of Finnish Life Insurance Companies, the University of Helsinki and Novo Nordisk A/S, Bagsvaerd, Denmark. We thank Susanna Heikkilä and Riitta Päkkilä for their excellent technical assistance, Juha Nuotio for assistance with the software and Jukka Bergström with the hardware for the IA-2A assay and Associate Professor Esa Läärä for help in statistical issues. The Childhood Diabetes in Finland (DiMe) Study Group is composed of the following members:

Principal investigators: H. K. Åkerblom, J. Tuomilehto

Coordinators: R. Lounamaa, L. Toivonen

Data management: E. Virtala, J.Pitkäniemi

Local investigators: A.Fagerlund, M.Flittner, B. Gustafsson, M.Häggquist, A.Hakulinen, L.Herva, P.Hiltunen, T.Huhtamäki, N.-P.Huttunen, T.Huupponen, T. Joki, R. Jokisalo, M.L. Käär, S.Kallio, E.A.Kaprio, U.Kaski, M.Knip, L.Laine, J.Lappalainen, J. Mäenpää, A.- L. Mäkelä, K. Niemi, A. Niiranen, A.Nuuja, P.Ojajärvi, T.Otonkoski, K.Pihlajamäki, S.Pöntynen, J. Rajantie, J.Sankala, J.Schumacher, M.Sillanpää, M.-R.Ståhlberg, C.-H.Stråhlmann, T.Uotila, M.Väre, P. Varimo, G. Wetterstrand.

Special investigators: A. Aro, M.Hiltunen, H.Hurme, H. Нyöty, J. Ilonen, J. Karjalainen, M. Knip, P. Leinikki, A. Miettinen, T.Petäys, L. Räsänen, H. Reijonen, A. Reunanen, T. Saukkonen, E. Savilahti, E. Tuomilehto-Wolf, P. Vähäsalo, S. M. Virtanen. 


\section{References}

1. Christie MR (1996) Islet cell autoantigens in type 1 diabetes. Eur J Clin Invest 26: 827-838

2. Bottazzo GF, Florin-Christensen A, Doniach D (1974) Islet cell antibodies in diabetes mellitus with autoimmune polyendocrine deficiencies. Lancet II: 1279-1282

3. Palmer J, Asplin C, Clemons P et al. (1983) Insulin antibodies in insulin-dependent diabetics before insulin treatment. Science 222: 1337-1339

4. Baekkeskov S, Nielsen JH, Marner B, Bilde T, Ludvigsson J, Lernmark A (1982) Autoantibodies in newly diagnosed diabetic children immunoprecipitate human pancreatic islet cell proteins. Nature 298: 167-169

5. Baekkeskov S, Aanstoot H-J, Christgau S et al. (1990) Identification of the $64 \mathrm{~K}$ autoantigen in insulin-dependent diabetes as the GABA-synthesizing enzyme glutamic acid decarboxylase. Nature 347: 151-156

6. Christie MR, Hollands JA, Brown TJ, Michelsen BK, Delovitch TL (1993) Detection of pancreatic islet 64,000 $\mathrm{M}_{\mathrm{r}}$ autoantigens in insulin-dependent diabetes distinct from glutamate decarboxylase. J Clin Invest 92: 240-248

7. Rabin DU, Pleasic SM, Shapiro JA et al. (1994) Islet cell antigen 512 is a diabetes-specific islet autoantigen related to protein tyrosine phosphatases. J Immunol 152: 3183-3188

8. Lan MS, Lu J, Goto Y, Notkins AL (1994) Molecular cloning and identification of a receptor-type protein tyrosine phosphatase, IA-2, from human insulinoma. DNA Cell Biol 13: 505-514

9. Pietropaolo M, Hutton JC, Eisenbarth GS (1997) Protein tyrosine phosphatase-like proteins: link with IDDM. Diabetes Care 20: 208-214

10. Passini N, Larigan JD, Genovese S, Appella E, Sinigaglia F, Rogge L (1995) The 37/40-kilodalton autoantigen in insulin-dependent diabetes mellitus is the putative tyrosine phosphatase IA-2. Proc Natl Acad Sci USA 92: 9412-9416

11. Solimena M, Dirkx Jr RD, Hermel J-M et al. (1996) ICA512, an autoantigen of type I diabetes, is an intrinsic membrane protein of neurosecretory granules. EMBO J 15: 2102-2114

12. Gorus FK, Goubert P, Semakula C et al. (1997) IA-2-autoantibodies complement GAD- ${ }_{65}$-autoantibodies in new-onset IDDM patients and help predict impending diabetes in their siblings. Diabetologia 40: 95-99

13. Tuomilehto J, Lounamaa R, Tuomilehto-Wolf E et al. (1992) Epidemiology of childhood diabetes mellitus in Finland - background of a nationwide study of type 1 (insulindependent) diabetes mellitus. Diabetologia 35: 70-76

14. Bonifacio E, Lampasona V, Genovese S, Ferrari M, Bosi E (1995) Identification of protein tyrosine phosphatase-like IA2 (islet cell antigen 512) as the insulin-dependent diabetes-related $37 / 40 \mathrm{~K}$ autoantigen and a target of islet-cell antibodies. J Immunol 155: 5419-5426

15. Sambrook J, Fritsch EF, Maniatis T (1989) Plasmid vectors. In: Ford N, Nolan C, Ferguson M (eds) Molecular cloning: A laboratory manual, Cold Spring Harbor Laboratory Press, Cold Spring Harbor NY, pp 1.3-1.110

16. Petersen JS, Hejnaes KR, Moody A et al. (1994) Detection of $\mathrm{GAD}_{65}$ antibodies in diabetes and other autoimmune diseases using a simple radioligand assay. Diabetes 43: 459-467

17. Sabbah E, Kulmala P, Veijola R et al. (1996) Glutamic acid decarboxylase antibodies in relation to other autoantibodies and genetic risk markers in children with newly diag- nosed insulin-dependent diabetes. J Clin Endocrinol Metab 81: 2455-2459

18. Bonifacio E, Lernmark Å, Dawkins RL (1988) Serum exchange and use of dilutions have improved precision of measurement of islet cell antibodies. J Immunol Methods 106: 83-88

19. Lernmark Å, Molenaar JL, van Beers VA (1991) The fourth international serum exchange workshop to standardize cytoplasmic islet cell antibodies. Diabetologia 34: 534-535

20. Tuomilehto Wolf E, Tuomilehto J, Cepaitis Z, Lounamaa R, the Childhood Diabetes in Finland Study Group (1989) New susceptibility haplotype for type 1 diabetes. Lancet 2: 299-302

21. Nomenclature for factors of the HLA system (1984) In: Albert ED, Mayr WR (eds) Histocomatibility testing. Berlin Springer Verlag, 1984, pp. 4-8

22. Genovese S, Bonfanti R, Bazzigaluppi E et al. (1996) Association of IA-2 autoantibodies with HLA DR4 phenotypes in IDDM. Diabetologia 39: 1223-1226

23. Ilonen J, Reijonen H (1993) Special genetic features of the population in Nordic countries as related to risk of IDDM. Diabetes in the Young 29: 10-16

24. Bingley PJ, Christie MR, Bonifacio E et al. (1994) Combined analysis of autoantibodies improves prediction of IDDM in islet cell antibody-positive relatives. Diabetes 43: $1304-1310$

25. Bonifacio E, Genovese S, Braghi S et al. (1995) Islet autoantibody markers in IDDM: risk assessment strategies yielding high sensitivity. Diabetologia 38: 816-822

26. Arslanian SA, Becker D, Rabin B et al. (1985) Correlates of insulin antibodies in newly diagnosed children with insulin-dependent diabetes before insulin therapy. Diabetes 34: 926-930

27. Karjalainen J, Knip M, Mustonen A, Ilonen J, Åkerblom HK (1986) Relation between insulin antibody and complement-fixing islet cell antibody at clinical diagnosis of IDDM. Diabetes 35: 620-622

28. Hagopian WA, Sanjeevi CB, Kockum I et al. (1995) Glutamate decarboxylase-, insulin-, and islet cell-antibodies and HLA typing to detect diabetes in a general populationbased study of Swedish children. J Clin Invest 95: 1505-1511

29. Vähäsalo P, Miettinen A, Kulmala P et al. (1997) GAD antibodies are associated with thyroid antibodies in children with IDDM and in their siblings. Diabetologia 40 [Suppl 1]: A77 (Abstract)

30. Pagano G, Cavallo-Perin P, Cavalot F et al. (1987) Genetic, immunologic, and environmental heterogeneity of IDDM. Incidence and 12-mo follow-up of an Italian population. Diabetes 36: 859-863

31. Serjeantson S, Court J, Mackay I et al. (1993) HLA-DQ genotypes are associated with autoimmunity to GAD in IDDM patients. Hum Immunol 38: 97-104

32. Verge CF, Gianini R, Kawasaki E et al. (1996) Prediction of type 1 diabetes in first-degree relatives using a combination of insulin, GAD and ICA512bcd/IA-2 autoantibodies. Diabetes 45: 926-933

33. Roll U, Ziegler AG (1997) Combined antibody screening for improved prediction of IDDM. Modern strategies. Exp Clin Endocrinol Diabetes 105: 1-14

34. Kulmala P, Savola K, Petersen JS et al. (1998) Prediction of insulin-dependent diabetes mellitus in siblings of children with diabetes - a population-based study. J Clin Invest 101: $327-336$ 